\title{
Assessment of Undiscovered Biogenic Gas Resources, North-Central Montana Province
}

Application of

a geology-based assessment methodology by the U.S. Geological Survey resulted in an estimated mean of 6,192 billion cubic feet of shallow biogenic (continuous) undiscovered gas in the NorthCentral Montana Province. Oil, gas, and natural gas liquids in conventional accumulations were not assessed.

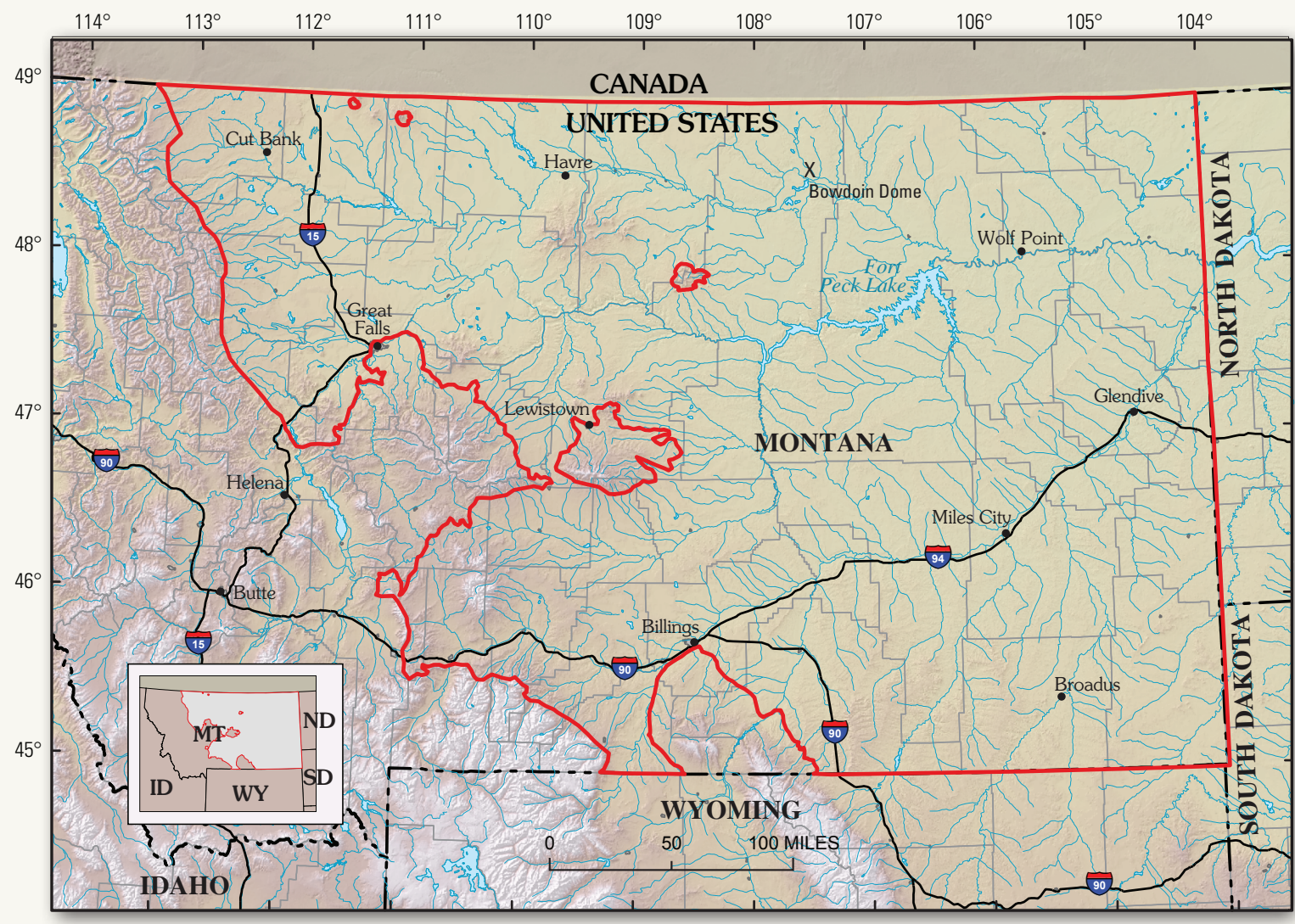

Figure 1. Map showing the North-Central Montana Province (enclosed by red line) in eastern Montana. Small closed polygons within the province are areas where source or reservoirs rocks are not present.

\section{Introduction}

In 2000 the U.S. Geological Survey (USGS) assessed the undiscovered biogenic (also known as microbial) continuous gas resource potential of the North-Central Montana Province in eastern Montana (fig. 1) as part of a national oil and gas assessment project. The assessment was based on the general geologic elements used to define a total petroleum system (TPS), including hydrocarbon source rocks (hydrocarbon generation and migration), reservoir rocks (sequence stratigraphy and petrophysical properties), and hydrocarbon traps (trap formation and timing). Using this geologic framework, the USGS defined the Cretaceous Judith River through Belle Fourche Biogenic Gas TPS and seven assessment units (AUs) within it, and quantitatively estimated the undiscovered continuous gas resources within each AU.

\section{Resource Summary}

Assessment of the undiscovered continuous gas resources for the seven AUs - Judith River Formation AU, Eagle Sandstone and Claggett Shale East AU, Eagle Sandstone and Claggett Shale West AU, Niobrara-Carlile AU, Greenhorn-Lower Belle Fourche AU, Greenhorn-Upper Belle Fourche AU, and Bowdoin Dome AU-resulted in an estimated total mean of 6,192 billion cubic feet (BCFG) of continuous biogenic gas in fields within the Cretaceous Judith River through Belle Fourche Biogenic Gas TPS (table 1). The Eagle Sandstone and Claggett Shale West and East AUs contain a combined estimated mean of 2,334 BCFG, representing 37.6 percent of the total undiscovered microbial gas resources. The Judith River Formation AU contains an estimated mean of 1,855 BCFG, representing an additional 30 percent of the total resource. Undiscovered petroleum (oil, gas, and natural gas liquids) in conventional accumulations in the province was not assessed at this time. 
Table 1. North-Central Montana Province basin assessment results.

[MMBO, million barrels of oil. BCFG, billion cubic feet of gas. MMBNGL, million barrels of natural gas liquids. Results shown are fully risked estimates. F95 represents a 95-percent chance of at least the amount tabulated; other fractiles are defined similarly. TPS, total petroleum system; AU, assessment unit. Gray shading indicates not applicable.]

\begin{tabular}{|c|c|c|c|c|c|c|c|c|c|c|c|c|c|}
\hline \multirow{3}{*}{$\begin{array}{l}\text { Total Petroleum System } \\
\text { and Assessment Unit }\end{array}$} & \multirow{3}{*}{$\begin{array}{l}\text { Field } \\
\text { Type }\end{array}$} & \multicolumn{12}{|c|}{ Total Undiscovered Resources } \\
\hline & & \multicolumn{4}{|c|}{ Oil (MMBO) } & \multicolumn{4}{|c|}{ Gas (BCFG) } & \multicolumn{4}{|c|}{ NGL (MMBNGL) } \\
\hline & & F95 & F50 & F5 & Mean & F95 & F50 & F5 & Mean & F95 & F50 & F5 & Mean \\
\hline \multicolumn{14}{|c|}{$\begin{array}{l}\text { Cretaceous Judith River through } \\
\text { Belle Fourche Biogenic Gas TPS }\end{array}$} \\
\hline Judith River Formation AU & Gas & & & & & 550 & 1,529 & 4,250 & 1,855 & 0 & 0 & 0 & 0 \\
\hline $\begin{array}{l}\text { Eagle Sandstone and } \\
\text { Claggett Shale East AU }\end{array}$ & Gas & & & & & 501 & 1,070 & 2,283 & 1,189 & 0 & 0 & 0 & 0 \\
\hline $\begin{array}{l}\text { Eagle Sandstone and } \\
\text { Claggett Shale West AU }\end{array}$ & Gas & & & & & 473 & 1,025 & 2,221 & 1,145 & 0 & 0 & 0 & 0 \\
\hline Niobrara-Carlile AU & Gas & & & & & 42 & 114 & 305 & 136 & 0 & 0 & 0 & 0 \\
\hline $\begin{array}{l}\text { Greenhorn-Lower } \\
\text { Belle Fourche AU }\end{array}$ & Gas & & & & & 166 & 412 & 1,025 & 481 & 0 & 0 & 0 & 0 \\
\hline $\begin{array}{l}\text { Greenhorn-Upper } \\
\text { Belle Fourche AU }\end{array}$ & Gas & & & & & 211 & 544 & 1,400 & 641 & 0 & 0 & 0 & 0 \\
\hline Bowdoin Dome AU & Gas & & & & & 484 & 723 & 1,079 & 745 & 0 & 0 & 0 & 0 \\
\hline $\begin{array}{l}\text { Total Undiscovered } \\
\text { Continuous Gas Resources }\end{array}$ & & & & & & & & & 6,192 & & & & 0 \\
\hline
\end{tabular}

\section{For Further Information}

Geologic studies of total petroleum systems and assessment units, as well as reports on the methodology used in assessing undiscovered gas resources for the North-Central Montana Province and other provinces, are available at the USGS Central Energy Team Web site: http://energy.cr.usgs. gov/oilgas/noga/. Published geologic studies resulting from this assessment project include the following:

Condon, S.M., 2000, Stratigraphic framework of Lower and Upper Cretaceous rocks in central and eastern Montana: U.S. Geological Survey Digital Data Series DDS-57, one CD-ROM.

Fishman, N.S., Ridgley, J.L., and Hall, D.L., 2001, Timing of gas generation in the Cretaceous Milk River Formation, southeastern Alberta and southwestern Saskatchewan-Evidence from authigenic carbonates, in Christopher, J.E., Gilboy, C.F., Haidl, F.M., and Kreis, L.K., eds., Summary of Investigations 2001, Volume 1: Saskatchewan Geological Survey, Saskatchewan Energy and Mines Miscellaneous Report 2001-4.1 p. 125-136.

Hester, T.C., 1999, Prediction of gas production using well logs, Cretaceous of north-central Montana: The Mountain Geologist, v. 36, no. 2, p. 85-97.

Lillis, P.G., 2007, Upper Cretaceous microbial petroleum systems in north-central Montana: The Mountain Geologist, v. 44 , no. 1 , p. 11-35.

Ridgley, J.L., 2000, Lithofacies architecture of the Milk River Formation (Alderson Member of the Lea Park Formation), southwestern Saskatchewan and southeastern Alberta-Its relation to gas accumulation, in Christopher, J.E., Gilboy, C.F., Haidl, F.M., Harper, C.T., and Brown, C.L., eds., Summary of investigations 2000, Volume 1: Saskatchewan Geological Survey, Saskatchewan Energy and Mines Miscellaneous Report 2000-4.1, p. 106-120.
Ridgley, J.L., Hester, T.C., Condon, S.M., Anna, L.O., Rowan, E.L., Cook, T.A., and Lillis, P.G., 1999, Re-evaluation of the shallow biogenic gas accumulation, Northern Great Plains, USA-Is the similar gas accumulation in southeastern Alberta and southwestern Saskatchewan a good analog?, in Christopher, J.E., Delaney, G.D., Gilboy, C.F., Haidl, F.M., Harper, C.T., and Paterson, D.F., eds., Summary of Investigations 1999, Volume 1: Saskatchewan Geological Survey, Saskatchewan Energy and Mines Miscellaneous Report 99-4.1, p. 64-78.

Ridgley, J.L., McNeil, D.H., Gilboy, C.F., Condon, S.M., and Obradovich, J.D., 2001, Structural and stratigraphic controls on sites of shallow biogenic gas accumulations in the Upper Cretaceous Belle Fourche and Second White Specks-Greenhorn Formations of southern Alberta, Saskatchewan, and northern Alberta, in Anderson, D.S., Robinson, J.W., Estes-Jackson, J.E., and Coalson, E.B., eds., Gas in the Rockies: Rocky Mountain Association of Geologists, Denver, Colo., p. 241-270.

\section{North-Central Montana Province Assessment Team}

Jennie L. Ridgley (Task Leader), Lawrence O. Anna, Steven M. Condon, Neil S. Fishman, Timothy C. Hester, Paul G. Lillis, Elizabeth L. Rowan, Ronald R. Charpentier, Troy A. Cook, Robert A. Crovelli, Timothy R. Klett, and Christopher J. Schenk. 